\title{
Biomass availability in eastern Ontario for bioenergy and wood pellet initiatives
}

\author{
by Rachele Levin ${ }^{1}$, Sally Krigstin ${ }^{1}$ and Suzanne Wetzel
}

\begin{abstract}
Interest in wood-based bioenergy and pelletization is growing in Ontario, and the province is taking steps to encourage these new technologies. A survey of eastern Ontario sawmills was conducted to assess residue production and availability for bioenergy and pellet applications. Approximately 259000 oven dry tonnes of sawmill residues are produced annually in eastern Ontario, but most of this fibre is absorbed by existing markets and would not be available for bioenergy or pellet initiatives. However, another source of wood fibre exists that is both abundant and unutilized: traditional pulpwood. While establishment costs of bioenergy and pellet facilities are high, pulpwood is locally available in large quantities. Given the right incentives, bioenergy and pelletization could provide alternative energy sources and support the forest industry and rural economy.
\end{abstract}

Key words: sawmill residue, wood biomass, bioenergy, pellets, eastern Ontario

\section{RÉSUMÉ}

L'intérêt pour la bioénergie obtenue à partir du bois et la production de granules de bois est en croissance en Ontario et la province cherche à encourager ces nouvelles technologies. Un sondage effectué auprès des scieries de l'est de l'Ontario a été réalisé afin d'évaluer la production de résidus et leur disponibilité pour produire de la bioénergie et des granules. Près de 259000 tonnes sèches de résidus de scieries sont produites annuellement dans l'est de l'Ontario, mais la majeure partie de ces fibres est absorbée par des marchés existants et ne serait pas disponible pour des projets de bioénergie ou de granules. Cependant, une autre source de fibres de bois existe et est à la fois abondante et sous-utilisée : le bois à pâte traditionnel. Même si les coûts de mise en place d'usines de bioénergie et de granules sont élevés, le bois à pâte est disponible sur place en grandes quantités. En fonction des mesures incitatives, la bioénergie et la production de granules pourraient constituer des sources alternatives dénergie et supporter l'industrie forestière et l'économie rurale.

Mots clés : résidus de scierie, bioénergie, granules, est de l'Ontario

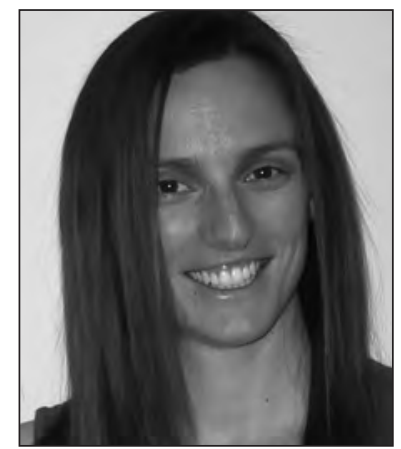

Rachele Levin

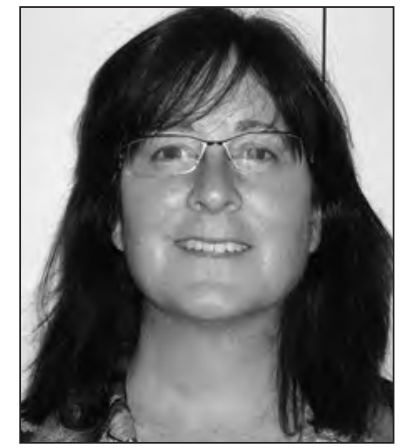

Sally Krigstin

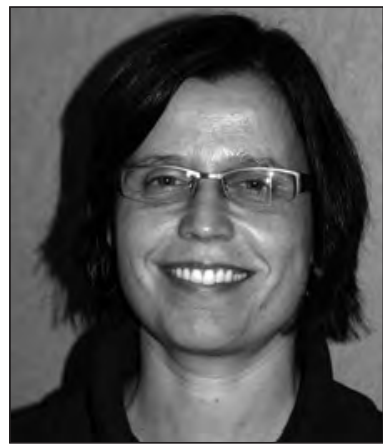

Suzanne Wetzel energy, particularly bio-based sources such as wood bioenergy (IEA Bioenergy 2007, Mabee 2009). The attraction of wood-based bioenergy is the possibility that it can address at once the multiple issues of energy sustainability, climate change, revitalization of forest industries and rural economic development (Tan et al. 2008). Developing wood-based bioenergy in local forest-dependent communities in Ontario could support local economic development and provide continued employment opportunities in the forest industry.

There has been increasing interest in wood bioenergy in Ontario as the province looks for alternate ways to generate electricity and heat. In 2008, Ontario approved the "Forest Biofibre - Allocation and Use" policy designed to support new technologies and opportunities to use forest biofibre in the province's Crown forests and to encourage the use of this forest biofibre to encourage the development of bioenergy

\footnotetext{
${ }^{1}$ Faculty of Forestry, University of Toronto, 33 Willcocks St., Toronto, Ontario M5S 3B3.

${ }^{2}$ Canadian Wood Fibre Centre, Natural Resources Canada, 1219 Queen St. E, Sault Ste. Marie, Ontario P6A 2E5. Corresponding author. E-mail: swetzel@nrcan.gc.ca
} 
and biofuels (OMNR 2007). In 2009 Ontario launched a call for expressions of interest to use Crown biofibre, and followed up later in the year with a request for proposals for a competition to use Crown wood supply in the province (OMNDMF 2009). Furthermore, the government of Ontario recently enacted a new Green Energy Act, designed to stimulate growth in renewable energies such as biomass (OMEI 2010). One of the major components of the Green Energy Act is a feed-in-tariff program, which allows companies or individuals to sell renewable energy — such as wood bioenergy-into the provincial grid at set rates. The new regulations under the Act also guarantee a streamlined approvals process and a service guarantee to bring developers greater certainty (OMEI 2010).

In recent years Canada's forest industries have been faced with a number of challenges, including a decline in the American housing market, continued threats of recession, an increase in value of the Canadian dollar against the American, and an increasing cost for transportation. These pressures have been exacerbated by increasing international competition in forest product manufacturing and a decline in demand for traditional forest products such as pulp and newsprint (Renfrew County 2006, Stone and Coughlin 2009). These challenges have led to mill closures, job losses and socioeconomic difficulties in regions throughout Canada, including eastern Ontario. The closure of the pulp and paper mill in Cornwall, Ontario in 2006 led to the loss of almost 3\% of local jobs and an equivalent loss of $\$ 83$ million annually to the local economy (Barkley and Lawn 2005).

Loss of traditional markets for wood fibre means that the survival of the forest industry depends on discovering new markets for the existing wood fibre that are both economically and environmentally sustainable (Chase 2009). By providing demand for wood fibre, wood-based bioenergy can address the issues of energy sustainability, revitalization of forest industries and rural economic development as well as new business opportunities for the forest industry (Speers 2009). There are currently a number of bio-based initiatives underway, such as the request for expression of interest to use Crown wood fibre, which drew over 100 applications for Crown fibre utilization in Ontario. In eastern Ontario, a plan to establish a Wood Centre and Eco-Industrial Park in the region is moving forward (OEWC 2010). A number of studies have been conducted on establishing wood-based bioenergy in the region, and a number of these outline the benefits of this new technology for the region (see, for example, Barkley and Lawn 2005, Hall 2009, Stone and Coughlin 2009).

\section{Research Objective}

To economically and sustainably produce wood bioenergy or bio-based products such as pellets, an area must have a sustainable supply of wood fibre. Thus, it is important to have a thorough understanding of the quantities of wood fibre available in eastern Ontario.

There are a number of potential sources of wood fibre available for new bio-energy-based industries including residues from sawmills (sawdust, chips, shavings and ends), "waste" material from harvesting and silvicultural operations (referred to as "slash"), plantation thinnings, and lower-quality roundwood (much of which was formerly used for pulpwood). This study focuses on assessing the amount of wood fibre available from two of the above-mentioned sources: sawmill residues (including bark, sawdust, chips and shavings) and the largely unmarketable roundwood that previously supplied the pulp market.

Studies on wood fibre procurement emphasize that fibre from whole trees and slash as compared to fibre from sawmill residues is typically more expensive to access and transport due to higher water content and lower energy density of the different forms of fibre (O'Carroll 2007). This means that unprocessed biomass can not typically be cost-effectively shipped more than about 50 to 100 miles by truck to its final destination (Pirraglia et al. 2010). The high costs of harvest and transportation together with the fuel characteristics of harvest residue can make this energy resource more expensive than coal. Wood fibre generated from sawmill residues, however, is generally drier than harvest residue and available in easily transportable forms such as sawdust, shavings and chips (Horgan 2002). Thus, these forms of woody residue have lower water content and higher energy density.

The original objective of this study was to determine the quantity of sawmill residues in eastern Ontario and assess the availability of these residues for the bioenergy market. A number of forest industry stakeholders in the region suggested that a large proportion of sawmill residues were well utilized and that there was a more significant wood fibre issue in eastern Ontario - this being the current lack of pulpwood markets and overabundance of pulpwood-quality fibre. Thus, this study also considers the potential use of pulpwood for the bioenergy market in eastern Ontario.

\section{Methods}

The study area is in the part of the province known as eastern Ontario (Fig. 1). Eastern Ontario includes the districts of Kemptville, Pembroke, Bancroft and Peterborough. Eastern Ontario has several advantages that support the merits of examining this region for bioenergy development. These include well-developed regional transport and forestry infrastructure, demand for local energy and heat, and a forwardlooking forest industry that is sincere in its efforts to develop bioenergy in the region (OEWC 2010).

The bulk of wood supplied to sawmills in eastern Ontario comes from four sustainable forest licences (SFLs) in the region: Algonquin Park Forest, Ottawa Valley Forest, Bancroft Minden Forest, and Mazinaw-Lanark Forest (Fig. 2). Based on the findings of this study, forests in eastern Ontario support a high percentage (30\% to $60 \%$ ) of low-quality trees that have almost no market value.

The majority of the forest land in this area is privately owned. In Renfrew County, for example, 53\% of forest lands are privately owned ${ }^{3}$ and in the area within the Eastern Ontario Model Forest this percentage exceeds 87\% (EOMF 2005). Unlike the northern part of the province, most sawmills in this area are small (process less than $5000 \mathrm{~m}^{3}$ annually). Many mills are family-owned and some have been in business for over a century (Renfrew County 2006). A list of mills in eastern Ontario was compiled using Ontario and Canadian government sources (McCloy and Associates Inc 2006, OMNR 2006), as well as company Web sites and webbased business and industry association directories ${ }^{3,4}$. The

\footnotetext{
${ }^{3}$ http://www.ont-woodlot-assoc.org/woodlot.html

${ }^{4}$ http://www.canadian-forests.com/forind.html
} 


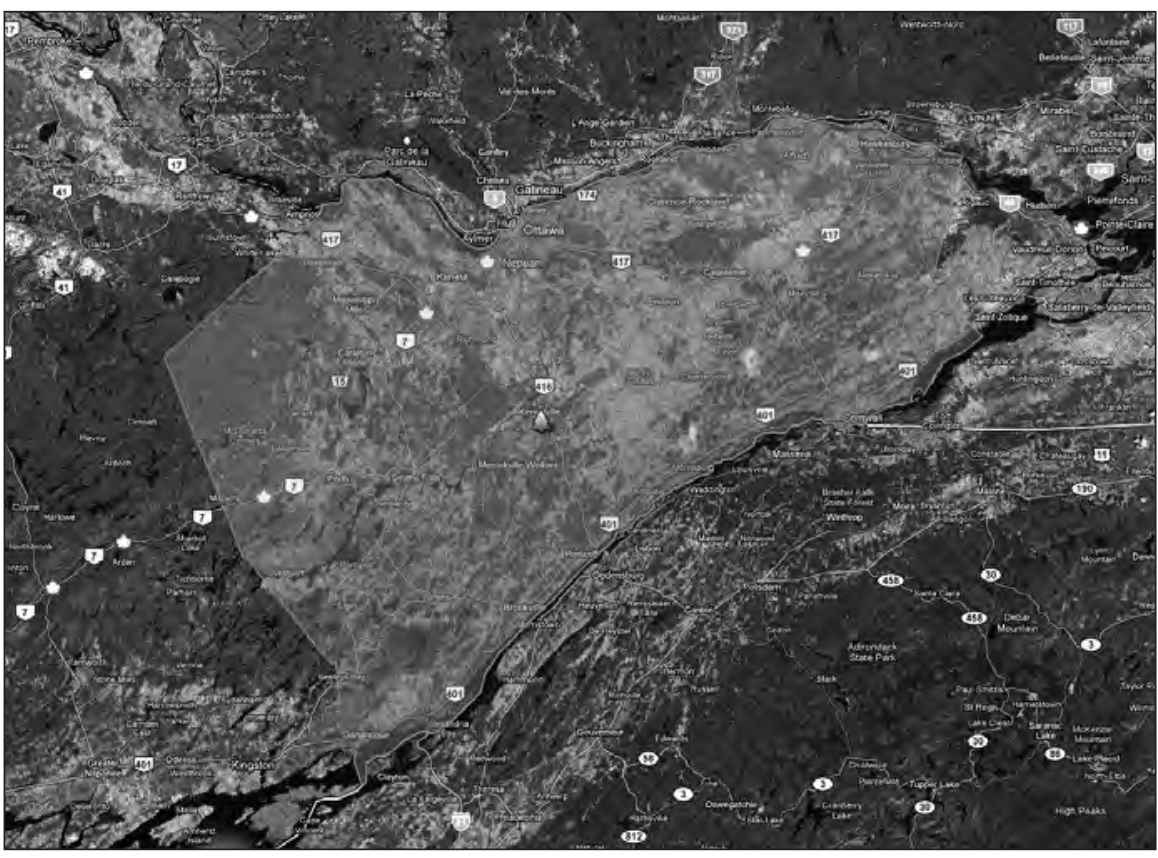

Fig. 1. Eastern Ontario with Eastern Ontario Model Forest core area highlighted. (Provided courtesy of EOMF].

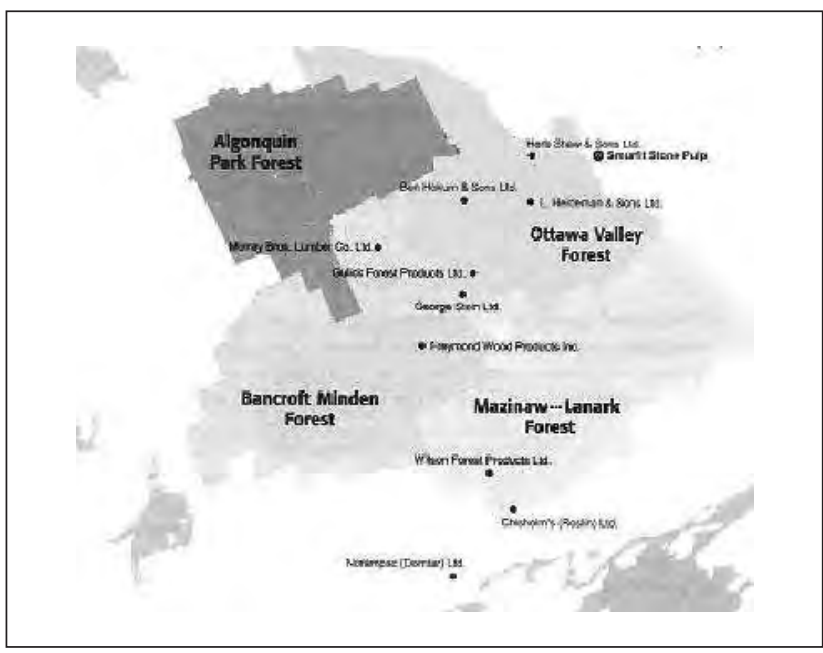

Fig. 2. Sustainable Forest Licences (SFLs) in eastern Ontario study region. Source: ValleyBio: Stone and Couglin (2009)

resulting database included 73 sawmills ranging in production capacity from less than $3000 \mathrm{~m}^{3}$ to over $50000 \mathrm{~m}^{3}$ per year. It was not confirmed whether all sawmills in the database were operational at the time of study as some were found to be permanently closed, temporarily shut down, or just non-operational at the time of the study.

Information on sawmill residues was gathered from interviews with mill owners, professionals from forestry organizations, and representatives from Sustainable Forest Licenses (SFLs) in the region. A structured interview was employed, which included 23 questions designed to collect information on production capacity, residue production, and disposal and pricing of residues. In total, 35 mills were contacted with requests to participate in this study. Thirty-two mills responded positively, resulting in over $90 \%$ of mills contacted expressing an interest in participating. Given mill closures and time constraints, 32 of the 73 mills were surveyed: 3 large, 11 medium, and 18 small mills. Mills were divided into three size categories based on MNR assessments of mills sizes (OMNR 2006). In order to preserve confidentiality and anonymity, mills are not identified by name. Averages were calculated from all collected data.

\section{Results and Discussion}

The forest industry in eastern Ontario was very responsive to requests for interviews. However, while some mill owners were eager to participate, it was considerably more difficult to obtain quantitative data on production capacity, residue generation, and residue pricing. Some mills, particularly smaller mills, either do not keep detailed information on residue generation or the quantities of residues produced are too small to be noted. Other mills were hesitant to disclose quantities. Most interviewees were reluctant to discuss residue pricing. Due to the difficulty in obtaining quantitative data, particularly for small and medium-sized mills, ascertaining an absolute quantity of sawmill residue availability in eastern Ontario was not possible. However, some quantitative information was disclosed and from this, as well as data from other studies, estimates of residue availability in the area were deduced.

Data were obtained on the volumes of woody raw material produced annually from SFLs as well as from private forests. While this is not used to calculate residue generation, it serves as a useful starting point to assess wood availability in the region. Overall, over 2.1 million $\mathrm{m}^{3}$ of raw material (round wood) are produced annually in eastern Ontario (Fig. 3).

\section{Residue generation}

Data collected through this study as well as from Hall (2009) allows a fairly accurate estimate of annual residues produced by the large mills in eastern Ontario (Table 1).

Due to a reluctance to disclose data or lack of data on residue generation, it was not possible to obtain data for all medium-sized mills. The largest mill to fall in the medium category produces approximately 67000 oven dry tonnes 5 (ODT) of residues per year, and the smallest produces 3270 ODT per year. The average residue production for medium mills is approximately 8000 ODT per year. Given that there

${ }^{5}$ It must be noted that the mill producing 67000 annual ODT of residues, while generating more residues than most large-sized mills, does not fall into the category of large mills because its overall production capacity is that of a typical medium-sized mill. In this particular case, the large quantity of residue production is not a result of overall production capacity. The mill in question runs a wood chipping operation in addition to its sawmilling operations. The chips produced from this side operation were included in the calculations of this study as "residues", but are strictly additional to residue production from sawmilling activities. 


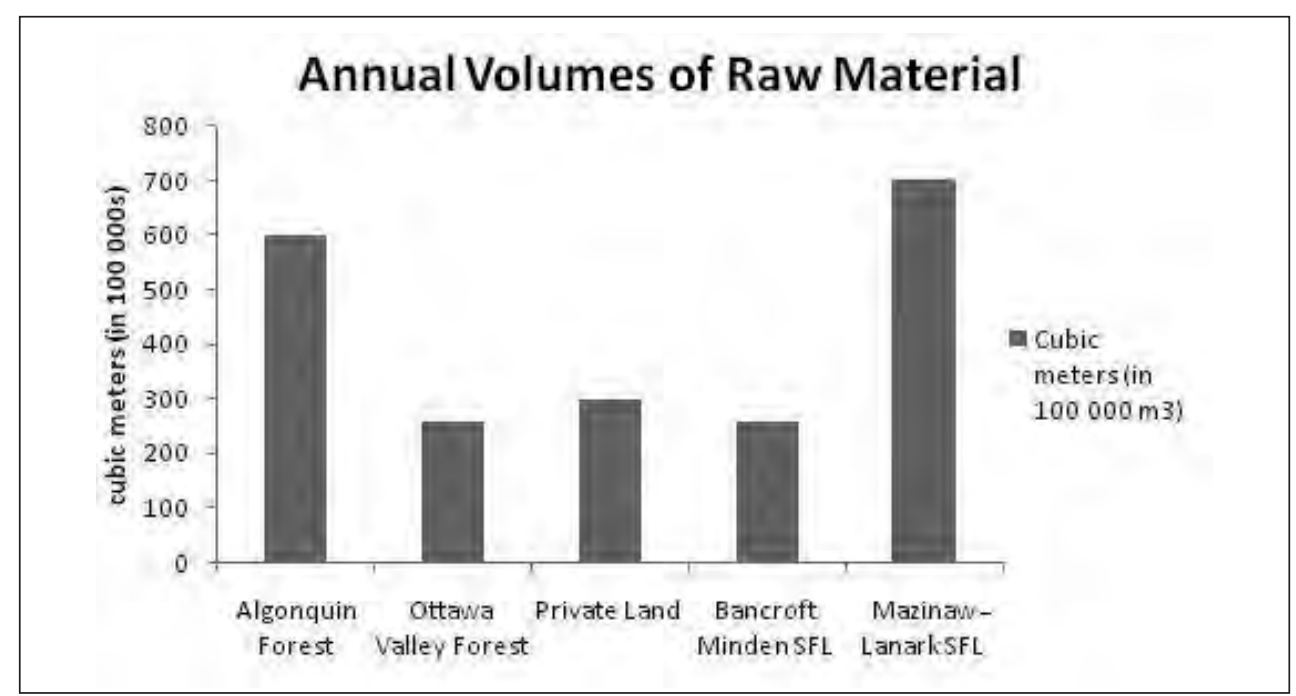

Fig. 3. Annual volumes of raw material (round wood) produced in eastern Ontario. Sources: Polk and Hall (2006), KBM Forestry Consultants Inc (2006), Mazinaw-Lanark Sustainable Forest License, Nitschke $^{6}$ (personal communication, 2009)

Table 1. Annual residue generation by large mills in eastern Ontario

\begin{tabular}{lcc}
\hline Mill & $\begin{array}{c}\text { Sawmill Residues } \\
\text { (green tonnes) }\end{array}$ & $\begin{array}{c}\text { Sawmill Residues } \\
(\text { ODT) }\end{array}$ \\
\hline $\mathbf{1}$ & 34000 & 17000 \\
$\mathbf{2}$ & 40000 & 20000 \\
$\mathbf{3}$ & 32000 & 16000 \\
$\mathbf{4}$ & 35000 & 17500 \\
$\mathbf{5}$ & 32000 & 16000 \\
Total & 173000 & 86500 \\
\hline
\end{tabular}

aassume $50 \%$ moisture content (wet basis)

Source: Data based on this study and Hall 2009

are 21 medium-size mills operating in eastern Ontario, they would generate approximately 168000 ODT per year. However, this is only an estimate, and actual residue generation could range from 105000 ODT to 190000 ODT per year depending on mill production volumes.

Small mills were the most reluctant to disclose quantitative information on production capacity and residue generation and also the least likely to have such data. Many small mills are no longer milling significant volumes of wood and have instead become retail and wood distribution centres, generating little to no residues. Of the 18 mills contacted, only two had documentation of residue production and were willing to share it. As quantitative results were only obtained from two small mills, it is very difficult if not impossible to draw broader conclusions. If these very limited results are extrapolated to the 47 small mills operating in eastern Ontario, one can approximate an average residue generation of 4935 ODT residues per year. However, this figure should only be considered as a crude estimate.

Overall, taking into account the more accurate estimates from large mills, the rudimentary estimates of medium mills,

${ }^{6}$ General Manager, Bancroft Minden Forest Company Inc. and the crude estimates for small mills, just over 259000 ODT of residues are produced every year by mills in eastern Ontario (Table 2).

Based on the results of this study, approximately 259435 ODT of residues are produced annually by sawmills in eastern Ontario. It is useful here to compare this figure to those reported by other sources. Based on information from the electronic Facility Information system (eFAR) and the Timber Resource Evaluation System (TREES) approximately 1.2 million $\mathrm{m}^{3}$ per year (average from 2003 to 2005) of wood (Crown and private land) was consumed by south eastern Ontario sawmills. Using the standard conversion factor of $40 \%$ (i.e., $40 \%$ of the wood fibre utilized by sawmills ends up as residue), an estimated $480000 \mathrm{~m}^{3}$ (240 000 ODT) of residue are produced annually. Furthermore, one can assume there is an additional $10 \%$ of wood fibre, accounting for $120000 \mathrm{~m}^{3}$ (60 000 ODT) of sawdust/shavings, that would be produced. Based on these calculations, total sawmill residues produced equals approximately 300000 ODT per year. Hence, there is good agreement between the findings of the study and the reported roundwood consumption.

Table 2. Estimate of quantities of residues produced per year by mills in eastern Ontario

\begin{tabular}{lcc}
\hline Mill size & $\begin{array}{c}\text { Residues } \\
\text { produced } \\
\text { annually - in ODT }\end{array}$ & $\begin{array}{c}\text { Average quantity } \\
\text { of residues } \\
\text { produced per mill } \\
\text { - in ODT }\end{array}$ \\
\hline Small & 4935 & 2467.5 \\
Medium & 168000 & 8000 \\
Large & 86500 & 17300 \\
Total & 259435 & 9609 \\
\hline
\end{tabular}

a assume 50\% moisture content (wet basis)

\section{Residue markets and prices}

Although this study as well as others (McCloy and Associates 2006, Bradley 2009) show that while there is a significant volume of residue generated by eastern Ontario sawmills, there is in fact little available for new market opportunities. Current residue supply is consumed by existing markets for mulch, animal bedding, pulp and paper plants, and panel board plants. Apart from supplying these markets, the forest products industry itself has long been utilizing sawmill residues to satisfy its own energy requirements. Between the current market demand and the use of residues by the forest industry itself, there is little excess residue available for new market 
opportunities. In fact, without exception, all respondents interviewed in this study said that while they are sending their residues farther away than in previous years, $100 \%$ of residues are being sold. Thus, the notion of "excess residues" or "waste" products does not exist in eastern Ontario.

At present, there is no single market price for sawmill residue in eastern Ontario. In fact, there is quite a large range in residue pricing (Table 3). According to Bradley (2008), prices paid for sawmill residue are generally set by negotiation and are usually for a maximum term of one year, sometimes even one load. While returns from residue sales are generally small, mills are still able to generate added revenue from their sale.

The fact that there is no surplus sawmill residue available in eastern Ontario does not preclude an opportunity to establish bioenergy or pellet production in the region. In actuality, there is a large underutilized wood resource readily available for which there is currently no market demand. This source of wood is the traditional pulpwood resource.

Table 3. Market prices for sawmill residues in eastern Ontario

\begin{tabular}{|c|c|c|}
\hline Residue & $\begin{array}{c}\text { This study: } \\
\text { Price per tonne } \\
\text { (in \$ CAD per ODT) }\end{array}$ & $\begin{array}{c}\text { Average } \\
\text { price per tonne } \\
(\$ C A D \text { per ODT })^{\mathrm{a}}\end{array}$ \\
\hline Sawdust & $\$ 35-\$ 45$ & $\$ 32.5$ \\
\hline $\begin{array}{l}\text { Wood chips, wood } \\
\text { shavings and ends }\end{array}$ & $\$ 80-\$ 90$ & N/A \\
\hline Bark (per green tonne) & $\$ 30-\$ 40$ & $\$ 45$ \\
\hline
\end{tabular}

aSource: Bradley 2008

\section{Other sources of woody biomass}

Throughout discussion with stakeholders in the eastern Ontario region other sources of woody biomass were identified as potential resources to support bioenergy initiatives.

\section{Heritage wood piles}

Heritage wood piles are composed of the by-products from sawmilling and other wood-processing activities, which were generated in the past and simply left in piles as they had no use at the time of generation. A 2006 study identified the amount of wood fibre available in heritage piles in eastern Ontario to be $360000 \mathrm{BDt}$ (bone dry tonnes) divided between three piles in and around Pembroke, Ontario (McCloy and Associates 2006). While this is a sizeable amount of fibre, there are significant risks associated with using this material as a bioenergy feedstock. The primary obstacles are the high concentration of moisture and contamination (dirt and rocks), which downgrade the fuel characteristics of the material (Stone 2006). These characteristics also adversely affect transportation and processing costs. Moreover, this resource is not sustainable as once exploited it is not renewed. Hence, this material may be of some benefit as an auxiliary supply in times of high biomass demand but can not be relied upon as part of the sustainable supply required by a bioenergy facility.

\section{Pulpwood}

The most significant findings of this study relate to the implications on pulpwood availability caused by the downturn in the pulp and paper industry in eastern Ontario. Pulpwood in eastern Ontario is comprised of lower-quality, unmerchantable wood from both hardwood and softwood species, including white and red pine, maple, birch and poplar. This lower-quality wood, for which there are presently limited markets, represents a high proportion of the forest cover in the region. In fact, forest owners report that between 55\% and $70 \%$ of all wood harvested in the area is of pulpwood quality, predominantly poplar and birch species. At present, this wood is being piled in forest landings and lumber yards, decomposing while awaiting new market opportunities.

On Crown land, the Crown Forest Sustainability Act and the associated ground rules, guidelines and standards require that these low-quality trees be removed on harvested areas in order to successfully regenerate a healthy and productive forest for the future. Without the removal of these trees, site preparation, planting and other operational treatments to meet forest management objectives face serious challenges and are much more expensive. Avoiding stands where there is an abundance of unmarketable species and concentrating the harvest on only the most operable stands is in effect a form of high-grading when the forest as a whole is considered. As mills cannot operate without access to the higher-quality material in the area, and the higher-quality material cannot be obtained without harvesting the pulpwood, a market for this pulpwood is needed in order for the existing forest industry to remain financially viable. In the early part of the century, there was an active market for local pulpwood. Demand for this wood came from the pulp and paper mills in the region. It is now apparent that pulp, paper and panel mills were essential to the health of both sawmill and forestry operations in the region, and their closures have left a financial gap in the forest industry and a resource for which there is no longer any demand (Table 4).

When the pulp, paper and panel mill industries in the region were active and profitable, they represented a sizeable market for pulpwood-quality material in eastern Ontario.

Table 4. Recent industry closures in the region

\begin{tabular}{llc}
\hline Mill & Location & Closing date \\
\hline Domtar & Cornwall, Ontario & 2006 \\
Domtar & Ottawa, Ontario & 2006 \\
ATC (MDF plant) & Pembroke, Ontario & 2007 \\
Smurfit-Stone & Portage du Fort, Quebec & 2008 \\
\hline
\end{tabular}

Their demise has created a considerable opportunity for wood-based bioenergy in the area. A bioenergy market could provide constant demand for both lower-quality wood and unmerchantable species that would not only provide the forest industry in eastern Ontario with a much-needed source of income, it could also encourage silvicultural activities for improved quality and species composition in the next generation of the forests in the region.

It is important to emphasize that bioenergy facilities must be located as close as possible to the source of wood fibre. Local supply is critical because freight constitutes 30\% to $50 \%$ of the value of a delivered load of pulpwood. For a low-value resource long distance hauls are not economically viable (Renfrew County 2006). 


\section{Volume of pulpwood in the area}

While this study did not set out to assess the amount of pulpwood available in eastern Ontario, it is important to gain an insight into this potential bioenergy resource. Approximately 2.1 million $\mathrm{m}^{3}$ per year of raw material is harvested from eastern Ontario's forests. Based on interview results, between $30 \%$ and $60 \%$ of harvests in eastern Ontario is comprised of pulpwood. Thus each year, between $630000 \mathrm{~m}^{3}$ and $1260000 \mathrm{~m}^{3}$ of pulpwood is available for new market opportunities. Polk and Hall (2006) made a similar estimate of $855000 \mathrm{~m}^{3}$ per year. A more recent study by Hall (2009) estimates that there is an annual supply of approximately 600000 metric tonnes of pulpwood available in eastern Ontario.

\section{Bioenergy and pelletization opportunity in eastern Ontario}

Woody biomass-based bioenergy comes in a variety of technologies and scales. These include direct combustion, co-firing (for example, with coal), gasification, pyrolysis and anaerobic digestion. A study by ValleyBio concluded that for eastern Ontario, major potential uses for wood fibre include direct combustion, bio-oil refining, gasification, and pelletization (Stone and Coughlin 2009). Recognizing that there are numerous technologies for generating bioenergy and other bio-products, this paper will focus only on direct combustion (specifically direct combustion generating combined heat and power - CHP) and pelletization, as these are reliable, proven technologies.

\section{Wood-fuelled combined heat and power (CHP) plant}

The simplest and most technologically sound means of utilizing wood fibre for energy in eastern Ontario is through direct combustion in a cogeneration facility. This proven technology provides a relatively inexpensive solution for generating electricity and heat from wood biomass (Lamb 1996). Cogeneration, or combined heat and power $(\mathrm{CHP})$, is the production of two kinds of energy - typically electricity and heat-from a single fuel source. Because these facilities generate both electricity and heat energy that might otherwise be wasted, CHP facilities can be significantly more efficient than stand-alone power generators. A number of existing forest industry facilities, including pulp and paper mills, sawmills and wood drying facilities, use the excess steam generated in cogeneration facilities to satisfy some of their steam and heat requirements. Tembec has a CHP plant at their Chapleau, Ontario sawmill that uses biomass to produce 7.2 MW of electricity and uses the heat and steam for internal processes. AbitibiBowater in Fort Frances, Ontario has installed a new 47-MW unit that will ultimately consume 600000 to 700000 tonnes of wood waste and forest residues (NOVA 2010).

CHP technology is widely used in Europe. Sweden, for example, has an extensive district (community) heating system fuelled by wood bioenergy (Ericsson et al. 2004). Compared to large coal- or gas-fuelled electricity plants, which have an efficiency of $30 \%$ to $40 \%$, small-scale biomass-based CHP systems have a low efficiency, ranging from $20 \%$ to $30 \%$. However, when both electricity and heat are utilized, the efficiency of these systems increases to $60 \%$ to $90 \%$ (IEA 2007). Therefore, proximity of the CHP facility to large consumers of heat such as office buildings, hospitals, schools or industrial complexes such as the proposed Ontario East Wood Centre and Eco-Industrial Park, is of utmost importance.

In eastern Ontario, a number of the mill owners were strongly supportive of the idea of a local, small-scale bioenergy facility being established there. A facility of this kind would be close to both the wood resource and consumers of heat and electricity. According to proponents, a bioenergy boiler on the order of $2 \mathrm{MW}$ to $5 \mathrm{MW}$ could be installed locally and could take advantage of local wood resources to minimize transport distances, thus controlling the costs. Small-scale CHP units are available commercially. Most importantly, because the wood is burned by direct combustion, CHP boilers are indiscriminate users of large volumes of biomass (Polk and Hall 2006). Thus, low-quality pulpwood, as well as forest harvest residue, regardless of species and condition, could be used in the generation of energy.

Small-scale CHP plants require approximately 20 oven dry tonnes per day (ODT/d) of biomass (40 green tonnes) for every MW of energy produced. Thus, for example, on an annual basis a $2 \mathrm{MW}$ plant would consume about 14600 dry tonnes, or 29200 green tonnes of wood fibre per year, operating 24 hours a day, 365 day per year (Biosystems Group 2007). Based on results from a number of Finnish studies examining the amount of heat and power available from $\mathrm{CHP}$ plants, a 2-MW CHP plant can be expected to produce between $0.5 \mathrm{MW}$ to $1.7 \mathrm{MW}$ of electric power, $1 \mathrm{MW}$ to 1.5 MW of district heating power, and almost $0.5 \mathrm{MW}$ of steam power (Aittola 2010). The results will depend significantly on the actual heat demand profile and the distance the heat has to travel from the CHP plant to the end users. Moreover, in the Finnish analysis it is assumed that the district heating system primarily supplies heat to private houses (Aittola 2010).

According to IEA Bioenergy (2009), the most critical issues in biomass logistics include the properties of the biomass itself (energy density, seasonal availability of biomass) and factors limiting the supply of biomass (availability and appropriateness of mechanized equipment, and inadequate infrastructure to access conversion facilities and markets).

\section{Wood pellets}

Establishment of a pellet plant in eastern Ontario is a second option for the under-utilized pulpwood resource in the area. Demand for wood pellets is increasing, particularly in Europe, where concern over the increasing price of fossil fuels and climate change have led to an increased demand for lowcarbon, renewable fuel sources (Stone and Coughlin 2009). As demand grows, prices for premium wood pellets have reached \$500 per tonne (Stone and Coughlin 2009). Nationally, Canada exports over 100000 tonnes of wood pellets to Europe (Jannasch et al. 2001), but consumes very little domestically. However, domestic demand has been forecasted to grow over the next decade as fuel prices rise (Deloitte \& Touche LLP 2009). In fact, Stone and Coughlin (2009) conclude that establishing a pellet plant in eastern Ontario could provide a useful new market for wood fibre in the region. At present, expansion of the wood pellet industry in Canada is limited only by a lack of surplus wood residues, particularly in the form of easily transported and relatively dry sawmill residues such as thinnings and sawdust (Jannasch et al. 2001). Because of the under-utilized quantities of pulpwood available in eastern Ontario, availability of wood fibre to supply a new pellet mill in the region is not considered an issue.

Given the increasing demand for wood pellets in Europe, there is considerable potential to expand wood pellet sales to that part of the world. Relative to many other locations, east- 
ern Ontario is particularly well placed to efficiently ship pellets to Europe. Shipping costs from the Great Lakes Region to Europe is estimated to be $\$ 35$ to $\$ 50$ per tonne (K. Smart Associates 2009). While international markets are important, some studies agree that one of the advantages for eastern Ontario is its close proximity to local markets in southern Ontario, Quebec and the north eastern seaboard of the United States (REAP-Canada 2009, NOVA 2010). According to REAP-Canada (2009), the potential for market development includes residential, commercial and industrial energy applications.

While the potential for wood pellets in eastern Ontario is considerable, cost must be considered in the overall feasibility analysis. The cost of pelletization in eastern Ontario is over $\$ 4.00 / G J$, which is higher than natural gas, almost 12 times more expensive than coal, and almost twice as expensive as pellet production elsewhere in the world (Table 5). Reasons for these high costs include higher costs of sawmill residues (likely due to decreasing supply of these residues) and high transportation costs.

While the cost of producing pellets in eastern Ontario could be lower if pellets are produced using the low-demand

Table 5. Cost of comparative fuels

\begin{tabular}{lccc}
\hline Fuel source & $\begin{array}{c}\text { Energy } \\
\text { content }\end{array}$ & $\begin{array}{c}\text { Cost per } \\
\text { unit }\end{array}$ & $\begin{array}{c}\text { Cost per } \\
\text { GJ }\end{array}$ \\
\hline Coal & $28 \mathrm{GJ} /$ tonne & $\$ 41 /$ tonne & $\$ 1.46$ \\
Natural gas & $0.0378 \mathrm{GJ} / \mathrm{m}^{3}$ & $\$ 0.45 / \mathrm{m}^{3}$ & $\$ 11.90$ \\
Pellets (world price) & $18 \mathrm{GJ} /$ tonne & $\$ 150 /$ tonne & $\$ 8.33$ \\
Pellets (Pembroke) & $18 \mathrm{GJ} /$ tonne & $\$ 288 /$ tonne & $\$ 16.00$ \\
\hline
\end{tabular}

Source: Stone 2006

pulpwood as opposed to high-demand sawmill residues, cost of pellet production with pulpwood would nonetheless be high due to the additional processing required. The wood must be harvested, transported, debarked, chipped and then dried. In fact, "green" wood fibre such as pulpwood will contain $50 \%$ moisture and would require considerable drying (K. Smart Associates 2009). The dry material must be ground or hammer-milled to a smaller particle size prior to pelletization. Sawdust and other sawmill residues have a reduced moisture level and are of smaller particle size and therefore can be processed directly into pellets. The extra handling and processing that would be required for pulpwood would increase the cost, and thus the operation must be carefully managed for cost efficiency in order to create a profitable business (NOVA 2010).

Given the high cost for pellet manufacturing and the relatively low cost of coal and natural gas, REAP Canada (2009) concludes that without a form of carbon tax or a renewable energy incentive program, the economic viability of pellet production remains marginal in today's energy environment. While pellet production may be more expensive than other forms of energy generation, it is possible that other developments in the province could affect the economic viability of wood pellets as a fuel source. Ontario Power Generation's (OPG) commitment to eliminating coal in power generation in Ontario by 2014 could dramatically change the playing field in Ontario. OPG currently has $6315 \mathrm{MW}$ of coal-fired capacity in Ontario that will need to be replaced by alternative fuels. Moreover, Ontario is committed to greener energy and is seeking new sources of renewable energies. In this context, wood pellets may clearly have a larger role to play in the overall energy portfolio of the province.

\section{Policies to enhance bioenergy implementation in eastern Ontario}

The forest industry in Ontario employs direct combustion of sawmill residues and other wood fibre to generate energy for industrial needs. Furthermore, Ontario already houses a small number of pellet plants that produce pellets from wood fibre. However, more technologically complex bioenergy ventures such as small-scale CHP are not even available at the demonstration size. Because the concept of stand-alone bioenergy ventures is only emerging at present in Ontario, uncertainties exist along the value chain related to biomass procurement and availability, appropriate technologies and financial fit (Biosystems Group 2007).

The major obstacle facing the establishment of $\mathrm{CHP}$ in the province is the relatively low cost of alternative fuels such as natural gas and coal. Establishment costs for even small-scale CHP are high, ranging from $\$ 1.5$ to $\$ 3$ per MW installed (IEA 2007), while the cost of establishing coal and natural gas facilities are in the range of $\$ 0.8$ to $\$ 2.7$ per MW (OECD 2010). The relatively inexpensive nature of these fuels and the lower upfront investment is certainly an obstacle to the establishment of a wood-fuelled CHP. While OPG's promise to phase out Ontario's coal plants by 2014 will likely reconfigure the state of energy supply in the province, wood-based energy in the form of $\mathrm{CHP}$ will likely require additional government support to become successfully established in the province.

While the current low cost of fossil fuels in Ontario makes the economic viability of wood-based bioenergy in the province less appealing, there are some major indications that government leadership is already helping to level the playing field in favour of wood-based bioenergy. OPG's commitment to phase-out coal plants by 2014 and its interest in replacing coal with renewable woody fuels is a major victory for wood-based energy generation. Another extremely important policy decision related to wood-based bioenergy was the release of Ontario's Green Energy Act in May 2009. Apart from offering economic opportunities for renewable energy development in the province, the Green Energy Act also establishes a feed-in tariff for selling renewable energy, including power generated from CHP plants, back to the grid for a premium rate.

The federal regulatory environment is also beginning to take shape. In late 2009 the federal government created a 1 billion CAD tax credit program for energy upgrades. While some large forestry companies have qualified for tax credits under this plan, mills in eastern Ontario, which are much smaller in scale, have not been able to take advantage of this funding.

A number of significant policy decisions have been taken in Ontario in the past few years that are helping to level the energy playing field in the province so that renewable energy generation activities, including wood-based energy development, can compete with fossil fuels. In the long term, more strategic policy aimed at promoting wood-based energy is needed to support the development of bioenergy in Ontario. Useful policy directives that could promote a more long-term 
shift to wood-based and other renewable energies include utilizing a carbon tax to increase the price of fossil fuels to make bioenergy and other renewables more economically appealing, creating a market for biomass energy by providing financial incentives to businesses and residents to switch to bioenergy, and setting provincial targets for renewable energy use.

While it is not within the scope of this paper, it would be useful to assess the concrete, on-the-ground costs of establishing a bioenergy or pelletization facility in eastern Ontario and to assess these costs against funding options currently available. It would be useful to consider revenue from the feed-in tariff under the Green Energy Act as well as funding options, both provincial and federal, in order to determine the impacts of current policies and programs on the viability of wood-energy initiatives in eastern Ontario.

\section{Conclusion}

The economic difficulties created by the downturn in the traditional forest sector and the loss of markets for pulpwoodquality logs have created an opportunity for new markets in eastern Ontario. Closure of local pulp and panel mills coupled with increased international competition for wood and paper products have resulted in mill closures, lost jobs and concerns that many more will follow if sustainable, reliable markets cannot be found.

For the forest industry in eastern Ontario to remain viable, alternate markets for low-quality fibre and new business models are needed. Establishing bioenergy and/or pelletization facilities in the area would provide steady and sustained demand for the available resource. A small-scale CHP system for generating both electricity and heat is another option.

In eastern Ontario, the potential user market for smallscale bioenergy facilities, including office buildings, malls, schools, hospitals and industrial complexes could be substantial. While there are still hurdles to the development of bioenergy in eastern Ontario, such as competition from relatively inexpensive coal and natural gas, recent government initiatives have been working to level the playing field.

While this study serves as a general overview of the availability of wood fibre in eastern Ontario, and some potential uses for this fibre, comprehensive technological and cost-benefit studies need to be completed to determine the real potential and scope for a bioenergy project. Apart from determining appropriate size, location and technology for a wood energy or pellet project in the area, potential project proponents would need to determine with as much accuracy as possible the amount of pulpwood available within a given radius from a proposed facility. Thus, a study assessing the quantity of pulpwood fibre available within a fixed radius of the potential bioenergy site is essential. Furthermore, an economic and technical assessment of potential bioenergy facilities in the region is necessary to ensure that the proposed technology, scale and fibre availability are compatible.

\section{Acknowledgements}

First and foremost, we would like to thank all those who enthusiastically contributed to our survey and gave generously of their time to meet with us. We certainly appreciate your insights which gave substance to this project. Many thanks to C. Robinson of the Petawawa Research Forest and to the anonymous reviewers for reviewing the manuscript and providing valuable suggestions. We gratefully acknowledge financial assistance from the Eastern Ontario Model Forest, MITACS and the Canadian Wood Fibre Centre.

\section{References}

Aittola, J-P. 2010. Heat - Electricity Plants in Finland: Combined Heat \& Power Production (CHP) [online]. Available at http://next.utu.fi/2010/presentations/Aittola-CHP_power_in_Finland.pdf.

Barkely, B. and S. Lawn (eds.). 2005. Making Lemonade From Trees: How the Domtar Pulp Mill Shut Down is Creating New Opportunities for Eastern Ontario. A Community Response to the Shutdown of the Domtar Pulp Mill at Cornwall Ontario. Eastern Ontario Model Forest. 126 p. Available at http://www.eomf.on.ca/ en/bulletins-de-nouvelles/publications/information-reports/making-lemonade-from-trees-how-the-domtar-pulp-mill-shut-downis-creating-new-opportunities-for-eastern-ontario.

Biosystems Group. 2007. Accelerating Bio-energy Projects in Ontario - Workshop Discussion Document. From pre-feasibility study "Biomass and Thermal Conversion Technologies" (March 2007). Available at http://www.oceta.on.ca/ThermalConversionReport-Complete.pdf.

Bradley, D. 2008. Canada Report on Bioenergy 2008. IEA Task 40 Biotrade. Available at http://www.bioenergytrade.org/downloads/ canadacountryreportjun2008.pdf [Accessed Dec 7, 2010].

Bradley, D. 2009. Canada Report on Bioenergy 2009. IEA Task 40 Biotrade. Available at http://www.bioenergytrade.org/downloads/ canadacountryreportjuly72009adjmar232010.pdf [Accessed Dec 7, 2010].

Chase, S. 2009. Biomass may be answer to Renfrew County's forestry industry [online]. The Daily Observer. Available at http://www.thedailyobserver.ca/ArticleDisplay.aspx?archive=true\&e $=2155667$.

Deloitte \& Touche LLP. 2009. Wood pellet plant cost study for the forests of north eastern Ontario. Toronto, ON.

[EOMF] Eastern Ontario Model Forest. 2005. Wooded area by Ownership [online]. Available at http://sof.eomf.on.ca/ Biological_Diversity/Ecosystem/Cover/Indicators/Ownership/i_wo oded_area_by_ownership_e.htm [Accessed May 27, 2010].

Ericsson, K., Huttunen, S., Nilsson, L. J. and P. Svenningsson. 2004. Bioenergy policy and market development in Finland and Sweden. Energy Policy 32: 1707-1721.

Hall, L. 2009. Wood fibre availability in eastern Ontario and the potential for wood-based bioenergy in the region. Unpublished report.

Hirsch, R.L., R. Bezdek and R. Wendling. 2005. Peaking of world oil production: impacts, mitigation, and risk management [online]. Report to U.S. Dept. of Energy. Available at http://www.netl.doe.gov/ publications/others/pdf/Oil_Peaking_NETL.pdf.

Horgan, G. P. 2002. Wood energy economics [online]. Available at http://www.fao.org/docrep/005/Y4450E/y4450e08.htm.

[IEA] International Energy Agency. 2007. Biomass for power generation and CHP [online] Available at http://www.iea.org/Textbase/ techno/essentials3.pdf

IEA Bioenergy. 2009. Bioenergy - a sustainable and reliable energy source [online]. Available at http://www.ieabioenergy.com/LibItem.. spx $? \mathrm{id}=6479$.

Jannasch, R., Samson, R., De Maio, A. and T. Helwig. 2001. Switchgrass Fuel Pellet Production in Eastern Ontario: A Market Study. REAP-Canada Final Report to CANADAPT and the Agricultural Adaptation Council of Ontario. Ottawa.

K. Smart Associates Ltd. 2009. Bio Energy Commercial Agricultural Pellet Proposal (BECAPP): Phase 1 Feasibility Study. Available at http://www.rrfdc2.dynamic-site-builder.com/f/Feasibility_Study_ Report_Final.pdf.

KBM Forestry Consultants Inc. 2006. Algonquin Park Forest Wood Supply Analysis Evaluation. 10 p. Available at http://www.abr- 
web.ca/docs/KBM\%20Algonquin $\% 20$ Park\%20Wood\%20Supply\%20Evaluation.pdf.

Lamb, R. 1996. Forests, fuel and the future - Wood energy for sustainable development - Forestry topics report no. 5, Chapter 5 Technology transfer and energy transition. Available at http://www.fao. org/docrep/v9728e/v9728e00.htm.

Mabee, W. 2009. Setting the Stage: Emerging Bioenergy Opportunities in the Great Lakes Corridor [online]. Queen's University Institute for Energy and Environmental Policy, Kingston, ON. Available at http://www.northbay.ca/business/presentations/woodPellets/0903-05\%20Mabee\%202009\%20Emerging\%20bioenergy\%20opportunities\%20on\%20the\%20Great\%20Lakes\%20corridor.pdf

Mazinaw-Lanark Sustainable Forest Licence. 2006. Forest Management Plan for the Mazinaw-Lanark Forest Management Unit. Ontario Ministry of Natural Resources. Plan period April 1, 2006 to March 31, 2026. Available at http://www.appefmp.mnr.gov.on.ca/ eFMP/viewFmuPlan.do?fmu=140\&fid=100067\&type $=$ CUR RENT\&pid $=100067 \&$ sid $=0 \& p n=F P \& p p y f=2006 \& p p y t=2026 \& p t y f$ $=2006 \&$ ptyt $=2011 \&$ phase $=P 1$ [Accessed Dec. 7, 2010].

McCloy and Associates Inc. 2006. Estimated production, consumption and surplus mill wood residues in Canada, 2004. Natural Resources Canada, Canadian Forest Service, Headquarters, Ottawa, and the Forest Products Association of Canada. 60 p. Available at http://warehouse.pfc.forestry.ca/HQ/25989.pdf.

[NOVA] Northern Ontario Value-Added Initiative. 2010. Pellet Tool Kit [online]. Available at

http://www.solutionsforwood.com/_docs/newsletters/straightwoods_new/jan2010/NOVA_PelletToolKit_EN.pdf.

O'Carroll, A. 2007. Logging to save the planet? "Woody bioenergy" and climate change. Canadian Parks and Wilderness Society, Ottawa, ON. Available at http://www.cpaws.org/files/facts_woodybioenergy.pdf.

[OEWC] Ontario East Wood Centre. 2010. Ontario East Wood Centre and Eco-Industrial Park. [online]. Available at http://www. woodcentre.ca.

[OMEI] Ontario Ministry of Energy and Infrastructure. 2010. Ontario's Green Energy Act [online] Available at: http://www.mei. gov.on.ca/en/energy/gea/.

[OMNR] Ontario Ministry of Natural Resources. 2006. Forest Resource Processing Facilities (Mills) in Ontario [online]. Available at http://www.ontla.on.ca/library/repository/mon/14000/261068. pdf [Accessed Dec. 7, 2010].
.2007. Ontario's Forest Biofibre Policy (Draft) [online]. Available at http://www.ontla.on.ca/library/repository/mon/16000/ 272088.pdf [Accessed Dec. 7, 2010].

[OMNDMF] Ontario Ministry of Northern Development, Mines and Forestry. 2009. Ministry of Northern Development, Mines and Forestry Staged Competition for Crown Wood Supply in Ontario. Stage II: Provincial Wood Supply Competitive Process [online]. Available at http://www.mndmf.gov.on.ca/forestry/documents/ wscp_stage2_v4_2010.pdf [Accessed Dec. 7, 2010].

[OECD] Organization for Economic Development. 2010. Projected Costs of Generating Electricity 2010 Edition. 218 p. Available at http://www.iea.org/w/bookshop/add.aspx?id=403.

Pirraglia, A., Gonzalez, R., Saloni, D. and J. Wright. 2010. Wood pellets: An expanding market opportunity. Biomass Power and Thermal [online]. Available at http://www.biomassmagazine.com/ article.jsp?article_id=3853.

Polk, C. L. and L. Hall. 2006. Eastern Ontario Forest Utilization Study. Prepared for Renfrew County Community Futures Development Corporation. Renfrew County, ON.

Renfrew County. 2006. Renfrew County Forest Industry Survey [online]. Available at www.countyofrenfrew.on.ca/developmentproperty/RenfrewCtyForestIndustrySurveyMay06.pdf.

[REAP-Canada] Resource Efficient Agricultural Production Canada. 2009. Establishing Bioheat in Eastern Ontario Utilizing Switchgrass and Agricultural Biomass for Solid Fuel. Sainte Anne de Bellevue, QC. 22 p. Available at http://www.webtechcanada.com/ sdgcfdc/REAPCanadaFinalReport.pdf.

Speers, M. 2009. Research and Policy Challenges in Ontario's Forest Sector. Presentation by Ontario Ministry of Natural Resources (OMNR) at the University of Toronto, Toronto, ON.

Stone, R. 2006. Processing and Marketing of Sawmill and Agricultural Residuals in Renfrew County. Valley Bio Ltd., Cobden, ON. 41 p. Available at http://www.countyofrenfrew.on.ca/developmentproperty/processingandmarketingsawmills.pdf

Stone, R. and K. Coughlin. 2009. Crop and Wood Fiber Processing and Management. Valley Bio Ltd., Cobden, ON. 81 p. Available at http://www.rccfdc.org/cface/uploads/files/Crop\%20and\%20Wood\% 20Fiber\%20Processing\%20and\%20Management.pdf.

Tan, K.T., K.T. Lee and A.R. Mohamed. 2008. Role of energy policy in renewable energy accomplishment: The case of second-generation bioethanol. Energy Policy 36(9): 3360-3365. 